\title{
Different Aspergillus niger Strains and Inoculum Levels Affect the Nutritional Composition of Olive Leaves in Solid-state Fermentation
}

\begin{abstract}
Aydın Altop",a,*, Emrah Güngör1,b, Güray Erener ${ }^{1, c}$
${ }^{1}$ Department of Animal Science, Faculty of Agriculture, Ondokuz Mayis University, 55139 Samsun, Turkey *Corresponding author

A R T I C L E I N F O A B S T R A C T

Research Article

This study was conducted to investigate the effects of Aspergillus niger strain and inoculum level on the nutritional composition of olive leaves. The experiment had a $2 \times 3$ factorial arrangement of treatments with two A. niger strains (ATCC 200345 [A] and ATCC 9142 [B]) and three inoculum levels $\left(10^{4}, 10^{6}\right.$, and $\left.10^{8}\right)$. Olive leaves were milled to $2 \mathrm{~mm}$ and fermented in solid-state by two different $A$. niger strains and analysed for nutritional composition. Crude protein (CP) was increased linearly as the inoculum level increased. Ether extract (EE) and crude fiber $(\mathrm{CF})$ were decreased linearly in A strain or quadratically in B strain with increased inoculum levels. Crude ash and nitrogen-free extract content did not differ among groups. Strain A increased neutral detergent fiber (NDF) at higher inoculum level, whereas NDF was decreased as inoculum level increased in B strain. The lowest acid detergent fiber (ADF) was obtained from the B strain or $10^{6}$ inoculum level. The results showed that the effect of two strains on CP and ADF changed similarly with increased inoculum levels. However, two strains affected EE, CF, and NDF content differently with increased inoculum levels. The optimal situations were $10^{8}$ inoculum level for higher $\mathrm{CP}, \mathrm{A} 10^{4}$ or $\mathrm{B} 10^{4}$ for higher $\mathrm{EE}, \mathrm{B} 10^{6}$ for lower $\mathrm{CF}, \mathrm{B} 10^{6}$ or $\mathrm{B} 10^{8}$ for lower $\mathrm{NDF}, 10^{6}$ inoculum level or $\mathrm{B}$ strain for lower ADF. B strain at $10^{6}$ inoculation level can be preferred to obtain an average $\mathrm{CP}$ and $\mathrm{EE}$ content and lower CF, NDF, and ADF content.

Keywords: Aspergillus niger Inoculum level Nutritional composition Solid-state fermentation

Received : 05/10/2021

Accepted : 08/11/2021
\end{abstract}

https://orcid.org/0000-0002-3966-300X

Ditps://orcid.org/0000-0002-8025-2560 b@emrah.gungor@omu.edu.tr

https://orcid.org/0000-0003-4380-6162

\section{(c) () () () This work is licensed under Creative Commons Attribution 4.0 International License}

\section{Introduction}

The rapid increase in the world population caused a necessity to produce more animal products. With rapid development in animal husbandry, the demand for protein feed was increased around the world in the last decades. Protein sources currently used in animal nutrition will not be enough to meet the demand in animal nutrition, considering that many feed sources are also used in human nutrition. In recent years, several researchers have drawn attention to the utilization of agricultural residues.

Olive leaf is a by-product of the olive industry that emerged in the pruning and harvesting period (MolinaAlcaide and Yáñez-Ruiz, 2008). The discarded olive leaves constitute $10 \%$ of the total weight of harvested olives every year (Guinda et al., 2004). Considering that the total olive production is 21 million tons in 2017 (FAOSTAT, 2017), approximately 2.1 million tons of olive leaves are discarded each year. This causes transportation issues for the factories and also environmental problems.
Olive leaves improve egg production in quails (Christaki et al., 2011), improve immunity (Varmaghany et al., 2013) and intestinal microflora in broilers (Sarica and Urkmez, 2016), and increase antioxidant capacity in egg yolk (Botsoglou et al., 2010). Olive leaves can also improve the fatty acid profile of sheep and goat milk (Abbeddou et al., 2011a; Tsiplakou and Zervas, 2008), enhance egg yolk colour in laying hens (Cayan and Erener, 2015) and quails (Christaki et al., 2011) and reduce abdominal fat (Shafey et al., 2013) in broiler chickens. However, olive leaves can impair the growth performance of broiler chickens (Xie et al., 2016), reduce the milk yield of sheep (Abbeddou et al., 2011b), and worsen the ruminal fermentation in ruminants (Yanez Ruiz et al., 2004). These negative results may be due to the low nutritional composition of olive leaf and its anti-nutritional components (Martín-García et al., 2003). 
Solid-state fermentation has become a useful method used in the utilization of agro-industrial residues in animal nutrition in recent years. Altop (2019) reported that nutritional composition of olive leaves was improved by Aspergillus niger solid-state fermentation. However, different $A$. niger strains are reported to having different effects on the nutritional content of olive leaves (Altop et al., 2018). Similarly, the inoculum level is one of the important factors affecting the yield in solid-state fermentation (Lakshmi et al., 2009). Altop et al. (2018) investigated the effect of different $A$. niger strains on the nutritional composition of olive leaves. However, there is a lack of information about the effects of different inoculum levels of $A$. niger strains on the nutritional quality of olive leaves. Therefore, the effects of A. niger strains (ATCC 200345 [A] and ATCC 9142 [B]) and three inoculum levels $\left(10^{4}, 10^{6}\right.$ and $\left.10^{8}\right)$ on the nutrient composition of olive leaves were investigated in this study.

\section{Material and Methods}

\section{Strains and olive leaves}

Aspergillus niger strains (ATCC 200345 and ATCC 9142) were obtained from American Type Culture Collection (ATCC). Olive leaves were harvested from an olive garden in Aydın province. Olive leaves were dried on a bench after collection from the trees and stored at room temperature until the fermentation process.

\section{Solid-state fermentation}

Olive leaves were divided into six treatment groups after milling to $2 \mathrm{~mm}$ size. They were inoculated with two different A. niger strains (ATCC 200345 [A] and ATCC 9142 [B]) at three inoculum levels $\left(10^{4}, 10^{6}\right.$, and $\left.10^{8}\right)$. Crude protein (CP), ether extract (EE), ash, crude fiber $(\mathrm{CF})$ were determined according to AOAC (2000). The neutral detergent fiber (NDF) and acid detergent fiber (ADF) analyses were performed according to Van Soest et al. (1991).

\section{Statistical analysis}

Differences between the treatment groups were tested using ANOVA for $2 \times 3$ factorial design. Mean differences were determined using Duncan's multiple range test. Differences were considered significant using 95\% confidence limits $(\mathrm{P}<0.05)$. All statistical analyses were performed using SPSS (version 21.0; SPSS, Chicago, IL).

\section{Results and Discussion}

Nutritional changes in olive leaves after solid-state fermentation are given in Table 1 . There was a linear increase $(\mathrm{P}<0.001)$ in $\mathrm{CP}$ with increased inoculum level (Figure 2a). Gungor et al. (2017) noted that A. niger can increase the $\mathrm{CP}$ content of the substrates may be due to produced enzymes and own mycelia. Increased CP content by fermentation was reported in the studies on Ginkgo biloba (Zhang et al., 2013; Zhao et al., 2013), Moringa oleifera (Wang et al., 2018), and Larrea tridentata leaves (Aguilar et al., 2008).

Ether extract content was decreased as inoculum level increased in A strain, whereas EE was decreased in B10 $60^{6}$ and did not differ in $\mathrm{B} 10^{8}$ compared with the $\mathrm{B} 10^{4}$ group (Figure 1 , strain $\times$ inoculum level, $\mathrm{P}<0.05)$. Similarly, decreased ash content was reported in the studies on mango kernel (Kayode and Sani, 2008), Terminalia catappa fruit meal (Apata, 2011), and sour cherry kernel (Gungor et al., 2017).

Table 1. Nutritional composition of olive leaves fermented with A. niger strains at different inoculum levels (\%, dry matter basis)

\begin{tabular}{|c|c|c|c|c|c|c|c|c|}
\hline Strain & Inoculum level & $\mathrm{CP}$ & $\mathrm{EE}$ & Ash & NFE & $\mathrm{CF}$ & NDF & $\mathrm{ADF}$ \\
\hline \multirow[t]{3}{*}{ ATCC 200345 (A) } & $10^{4}$ & 28.88 & $4.65^{\mathrm{a}}$ & 12.97 & 35.41 & $18.10^{\mathrm{b}}$ & $40.55^{b}$ & 30.05 \\
\hline & $10^{6}$ & 30.30 & $3.51^{\mathrm{bc}}$ & 12.31 & 36.51 & $17.36^{\mathrm{bc}}$ & $41.91^{\mathrm{a}}$ & 29.21 \\
\hline & $10^{8}$ & 31.18 & $3.00^{\mathrm{c}}$ & 12.91 & 35.68 & $17.24^{\mathrm{bc}}$ & $42.05^{\mathrm{a}}$ & 30.95 \\
\hline \multirow[t]{3}{*}{ ATCC 9142 (B) } & $10^{4}$ & 29.34 & $4.20^{\mathrm{ab}}$ & 12.63 & 33.93 & $19.91^{\mathrm{a}}$ & $42.61^{\mathrm{a}}$ & 30.07 \\
\hline & $10^{6}$ & 29.95 & $3.20^{\mathrm{c}}$ & 11.91 & 38.82 & $16.12^{\mathrm{d}}$ & $39.01^{\mathrm{c}}$ & 27.29 \\
\hline & $10^{8}$ & 30.81 & $3.73^{\mathrm{bc}}$ & 12.21 & 36.08 & $17.17^{\mathrm{c}}$ & $39.09^{c}$ & 29.37 \\
\hline SEM & & 0.209 & 0.158 & 0.234 & 0.535 & 0.296 & 0.376 & 0.324 \\
\hline \multicolumn{9}{|l|}{ Strain } \\
\hline ATCC 200345 & & 30.12 & 3.72 & 12.73 & 35.87 & 17.56 & 41.51 & 30.07 \\
\hline ATCC 9142 & & 30.03 & 3.71 & 12.25 & 36.28 & 17.73 & 40.23 & 28.91 \\
\hline \multicolumn{9}{|l|}{ Inoculum level } \\
\hline & $10^{4}$ & $29.11^{\mathrm{c}}$ & 4.42 & 12.80 & 34.67 & 19.00 & 41.58 & $30.06^{\mathrm{a}}$ \\
\hline & $10^{6}$ & $30.13^{\mathrm{b}}$ & 3.36 & 12.11 & 37.67 & 16.74 & 40.46 & $28.25^{b}$ \\
\hline & $10^{8}$ & $31.00^{\mathrm{a}}$ & 3.37 & 12.56 & 35.88 & 17.20 & 40.57 & $30.16^{\mathrm{a}}$ \\
\hline P-value & & & & & & & & \\
\hline Strain & & NS & NS & NS & NS & NS & $* *$ & $*$ \\
\hline Inoculum level & & $* * *$ & $* * *$ & NS & NS & $* * *$ & $*$ & $* *$ \\
\hline $\begin{array}{c}\text { Strain } \times \text { Inoculum level } \\
\text { Effects }\end{array}$ & & NS & $*$ & NS & NS & $* * *$ & $* * *$ & NS \\
\hline Linear & & $* * *$ & $* * *$ & NS & NS & $* * *$ & $*$ & NS \\
\hline Quadratic & & NS & $*$ & NS & $*$ & $* * *$ & NS & $* * *$ \\
\hline
\end{tabular}

${ }^{\mathrm{a}-\mathrm{d}}$ Means in the same row without common superscripts are significantly different from each other $(\mathrm{P}<0.05), *$ : $\mathrm{P}<0.05, * *: \mathrm{P}<0.01, * * *: \mathrm{P}<0.001, \mathrm{NS}$ : not significant, CP: crude protein, EE: ether extract, NFE: nitrogen-free extract, CF: crude fiber, NDF: neutral detergent fiber, ADF: acid detergent fiber, SEM: standard error of mean. 


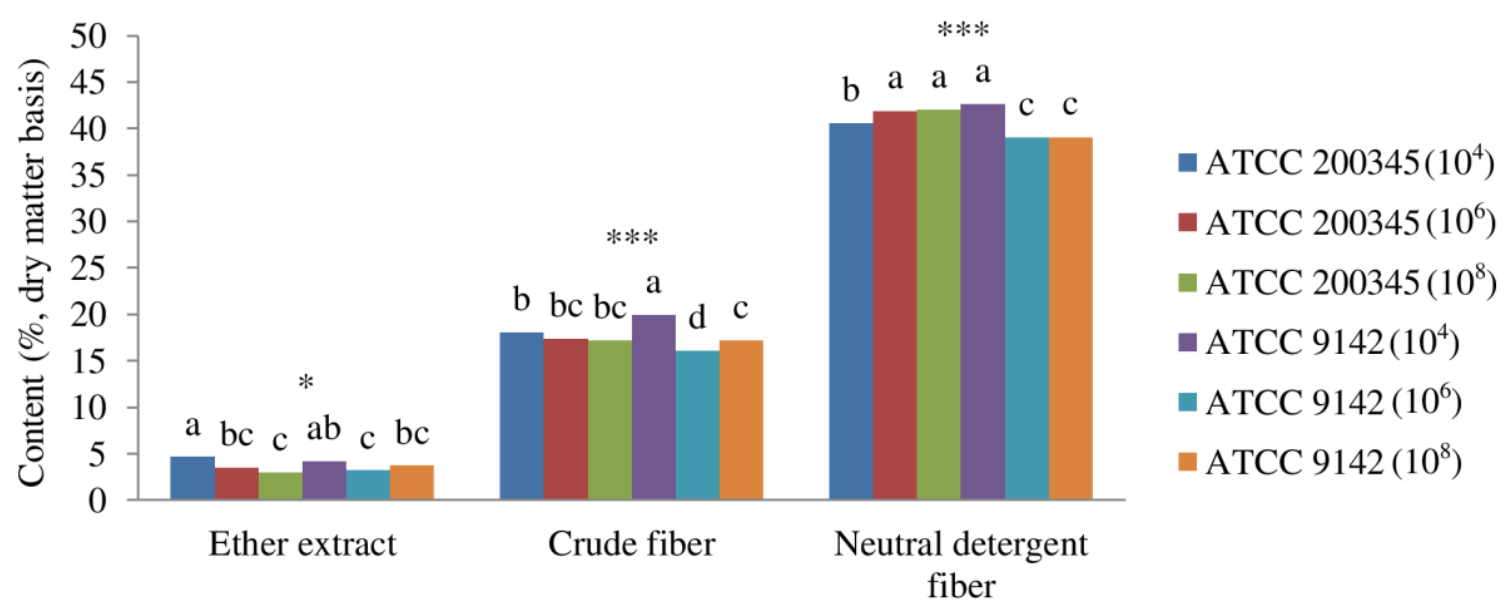

Figure 1. Interaction between inoculum level and strain on the ether extract, crude fiber and neutral detergent fiber content of olive leaves

a) Inoculum level

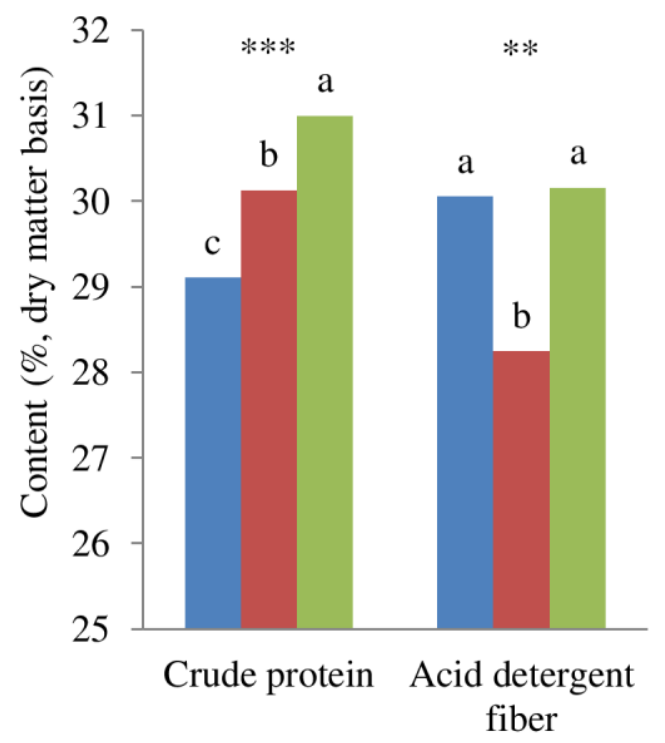

b) Strain

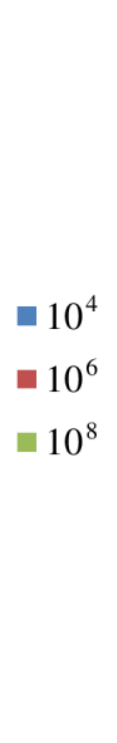

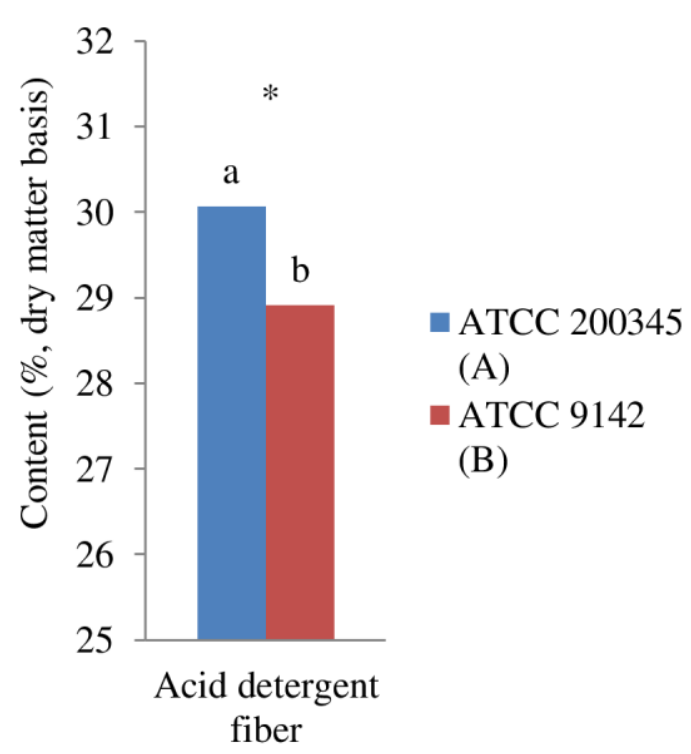

Figure 2. Effect of inoculum level (a) and strain (b) on the crude protein and acid detergent fiber content of olive leaves

The microorganisms firstly prefer soluble carbohydrates for use as a carbon source (Papagianni, 2007). Altop et al. (2018) noted that the nitrogen-free extract (NFE) content of olive leaves was decreased by solid-state fermentation. However, solid-state fermentation did not change the NFE content of olive leaves in the study. Similarly, Altop (2019) reported no change in the NFE content of olive leaves by A. niger.

Apata (2011) reported that fermentation decreased the ash content of $T$. catappa fruit meal. However, A. niger has been reported to increase the ash content of L. tridentata leaves (Aguilar et al., 2008) and G. biloba leaves (Zhang et al., 2013). In the present study, ash content was not significantly influenced $(\mathrm{P}>0.05)$ by solid-state fermentation. Similar results were obtained from the studies on palm kernel (Lawal et al., 2010) and rapeseed meal (Shi et al., 2016).

Increasing inoculum level caused a decrease in $\mathrm{CF}$ for $\mathrm{B}$ strain whereas $\mathrm{CF}$ was not changed by increasing level of inoculum in A strain (Figure 1, strain $\times$ inoculum level, $\mathrm{P}<0.001)$. Olive leaves in the $\mathrm{B} 10^{6}$ group had the lowest
$\mathrm{CF}$ content among the treatment groups. Aspergillus niger produces cellulase enzyme and degrades the CF content of the substrates (Xie et al., 2016). Solid-state fermentation decreased the CF content of olive leaves (Altop, 2019), palm kernel (Lawal et al., 2010) and grape seed (Gungor et al., 2021).

Strain A increased NDF at a higher inoculum level, whereas NDF decreased as inoculum level increased in B strain (Figure 1, strain $\times$ inoculum level, $\mathrm{P}<0.001$ ). The lowest NDF content was obtained from $\mathrm{B} 10^{6}$ or $\mathrm{B} 10^{8}$ groups. Gungor et al. (2017) noted that different A. niger strain affects the nutritional composition of the substrates differently, similar to the result of the present study. Aspergillus niger is reported to decrease the NDF content of shea nut (Dei et al., 2008), palm kernel (Lawal et al., 2010), and rapeseed meal (Shi et al., 2016).

ADF content was decreased by $10^{6}$ and was not differ by $10^{8}$ compared with $10^{4}$ inoculation level (Figure 2a) and the quadratic effect was significant $(\mathrm{P}<0.001)$. B strain had lower $(\mathrm{P}<0.05) \mathrm{ADF}$ than A strain (Figure $2 \mathrm{~b})$. Lakshmi et al. (2009) reported a quadratic effect of inoculum level on 
xylanase production, as in the ADF content in the present study. Similarly, Prakasham et al. (2006) showed that increasing inoculum level improves protease production at a certain level. But higher inoculum levels adversely affect enzyme production. Sandhya et al. (2005) also reported similar results on protease production.

\section{Conclusion}

Aspergillus niger improved the nutritional composition of olive leaves. Strains had different effects on EE, CF, and NDF with increasing inoculum levels. There was no significant difference among groups in ash and NFE content. Both strains increased CP content as the inoculum level increased. The lowest ADF content was obtained from A strain or $10^{6}$ inoculum level. B strain at $10^{6}$ inoculation level can be preferred to obtain the lowest $\mathrm{CF}$, $\mathrm{NDF}$, and ADF content and average $\mathrm{CP}$ and $\mathrm{EE}$ content.

\section{Article Information}

This study is an expanded version of the paper titled "Effect of Strain and Inoculum Level in Solid-state Fermentation on the Nutritional Composition of Olive Leaves" presented at the International Anatolian Agriculture, Food, Environment and Biology Congress held in Afyonkarahisar, Turkey on 20-22 April 2019, in line with the recommendations of the referees.

\section{References}

Abbeddou S, Rischkowsky B, Hilali ME-D, Hess HD, Kreuzer M. 2011a. Influence of feeding Mediterranean food industry by-products and forages to Awassi sheep on physicochemical properties of milk, yoghurt and cheese. Journal of Dairy Research, 78(4): 426-35. doi https://doi.org/10.1017/S0022029911000665.

Abbeddou S, Rischkowsky B, Richter EK, Hess H, Kreuzer M. 2011b. Modification of milk fatty acid composition by feeding forages and agro-industrial byproducts from dry areas to Awassi sheep. Journal of Dairy Science, 94(9): 4657-68 doi: https://doi.org/10.3168/jds.2011-4154.

Aguilar CN, Aguilera-Carbo A, Robledo A, et al. 2008 Production of antioxidant nutraceuticals by solid-state cultures of pomegranate (Punica granatum) peel and creosote bush (Larrea tridentata) leaves. Food Technology and Biotechnology, 46(2): 218-22.

Altop A. 2019. Effect of solid-state fermentation on main nutritional components, some minerals, condensed tannin and phenolic compounds of olive leaves. Turkish Journal of Agriculture-Food Science and Technology, 7(1): 115-9. doi: https://doi.org/10.24925/turjaf.v7i1.115-119.2231.

Altop A, Coskun I, Filik G, et al. 2018. Amino acid, mineral, condensed tannin, and other chemical contents of olive leaves (Olea europaea L.) processed via solid-state fermentation using selected Aspergillus niger strains. Ciencia e Investigación Agraria, 45(3): 220-30. doi: https://doi.org/10.7764/rcia.v45i3.1886.

AOAC. 2000. Official Methods of Analysis of AOAC International (17. Edition). Place of publication: USA: AOAC International.

Apata DF. 2011. Effect of Terminalia catappa fruit meal fermented by Aspergillus niger as replacement of maize on growth performance, nutrient digestibility, and serum biochemical profile of broiler chickens. Biotechnology Research International, 2011: 1-6. doi: https://doi.org/10.4061/2011/907546.
Botsoglou E, Govaris A, Moulas A, Botsoglou N. 2010. Oxidative stability and microbial growth of turkey breast fillets during refrigerated storage as influenced by feed supplementation with olive leaves, oregano and/or $\alpha$ tocopheryl acetate. British Poultry Science, 51(6): 760-8. doi: https://doi.org/10.1080/00071668.2010.532771.

Cayan H, Erener G. 2015. Effect of olive leaf (Olea europaea) powder on laying hens performance, egg quality and egg yolk cholesterol levels. Asian-Australasian Journal of Animal Sciences, $28(4)$ : $538 . \quad$ doi: https://doi.org/10.5713/ajas.14.0369.

Christaki E, Bonos E, Florou-Paneri P. 2011. Comparative evaluation of dietary oregano, anise and olive leaves in laying Japanese quails. Brazilian Journal of Poultry Science, 13(2): 97-101. doi: https://doi.org/10.1590/S1516635X2011000200003.

Dei H, Rose S, Mackenzie A, Amarowicz R. 2008. Growth performance of broiler chickens fed diets containing shea nut (Vitellaria paradoxa, Gaertn.) meal fermented with Aspergillus niger. Poultry Science, 87(9): 1773-8. doi: https://doi.org/10.3382/ps.2008-00055.

FAOSTAT. Food and Agriculture Organization of the United Nations. 2017.

Guinda Á, Pérez-Camino MC, Lanzón A. 2004. Supplementation of oils with oleanolic acid from the olive leaf (Olea europaea). European Journal of Lipid Science and Technology, 106(1): 22-6. doi: https://doi.org/10.1002/ejlt.200300769.

Gungor E, Altop A, Erener G. 2021. Effect of raw and fermented grape seed on growth performance, antioxidant capacity, and cecal microflora in broiler chickens. Animal, 15(4): 100194. doi: https://doi.org/10.1016/j.animal.2021.100194.

Gungor E, Altop A, Ozturk E, Erener G. 2017. Nutritional changes of sour cherry (Prunus cerasus) kernel subjected to Aspergillus niger solid-state fermentation. Journal of Tekirdag Agricultural Faculty, The Special Issue of 2nd International Balkan Agriculture Congress: 99-103.

Kayode R, Sani A. 2008. Physicochemical and proximate composition of mango (Mangifera indica) kernel cake fermented with mono-culture of fungal isolates obtained from naturally decomposed mango kernel. Life Science Journal, 5(4): 55-63.

Lakshmi GS, Rao CS, Rao RS, Hobbs PJ, Prakasham RS. 2009. Enhanced production of xylanase by a newly isolated Aspergillus terreus under solid state fermentation using palm industrial waste: A statistical optimization. Biochemical Engineering Journal, 48(1): 51-7. doi: https://doi.org/10.1016/j.bej.2009.08.005.

Lawal T, Iyayi E, Adeniyi B, Adaramoye O. 2010. Biodegradation of palm kernel cake with multienzyme complexes from fungi and its feeding value for broilers. International Journal of Poultry Science, 9(7): 695-701. doi: https://doi.org/10.3923/ijps.2010.695.701.

Martín-García A, Moumen A, Ruiz DY, Alcaide EM. 2003. Chemical composition and nutrients availability for goats and sheep of two-stage olive cake and olive leaves. Animal Feed Science and Technology, 107(1): 61-74. doi: https://doi.org/10.1016/S0377-8401(03)00066-X.

Molina-Alcaide E, Yáñez-Ruiz D. 2008. Potential use of olive byproducts in ruminant feeding: A review. Animal Feed Science and Technology, 147(1): 247-64. doi: https://doi.org/10.1016/j.anifeedsci.2007.09.021.

Papagianni M. 2007. Advances in citric acid fermentation by Aspergillus niger: biochemical aspects, membrane transport and modeling. Biotechnology Advances, 25(3): 244-63. doi: https://doi.org/10.1016/j.biotechadv.2007.01.002.

Prakasham R, Rao CS, Sarma P. 2006. Green gram husk-an inexpensive substrate for alkaline protease production by Bacillus sp. in solid-state fermentation. Bioresource Technology, $\quad 97(13)$ : $1449-54 . \quad$ doi: https://doi.org/10.1016/j.biortech.2005.07.015. 
Sandhya C, Sumantha A, Szakacs G, Pandey A. 2005. Comparative evaluation of neutral protease production by Aspergillus oryzae in submerged and solid-state fermentation. Process Biochemistry, 40(8): 2689-94. doi: https://doi.org/10.1016/j.procbio.2004.12.001.

Sarica S, Urkmez D. 2016. The use of grape seed-, olive leaf-and pomegranate peel-extracts as alternative natural antimicrobial feed additives in broiler diets. European Poultry Science, 80: $1-13$.

Shafey TM, Al-Ruqaei IM, Almufarij SI. 2013. Effect of feeding olive leaves extract (oleuropein) on the performance, nutrient utilization, small intestine and carcass characteristics of broiler chickens. Journal of Animal and Veterinary Advances, 12(6): 740-6.

Shi C, He J, Au J, et al. 2016. Physicochemical properties analysis and secretome of Aspergillus niger in fermented rapeseed meal. PloS one, 11(4): 1-16. doi: https://doi.org/10.1371/journal.pone.0153230.

Tsiplakou E, Zervas G. 2008. The effect of dietary inclusion of olive tree leaves and grape marc on the content of conjugated linoleic acid and vaccenic acid in the milk of dairy sheep and goats. Journal of Dairy Research, 75(3): 270-8. doi: https://doi.org/10.1017/S0022029908003270.

Van Soest Pv, Robertson J, Lewis B. 1991. Methods for dietary fiber, neutral detergent fiber, and nonstarch polysaccharides in relation to animal nutrition. Journal of Dairy Science, 74(10): 3583-97. doi: https://doi.org/10.3168/jds.S00220302(91)78551-2.
Varmaghany S, Rahimi S, Torshizi MK, Lotfollahian H, Hassanzadeh M. 2013. Effect of olive leaves on ascites incidence, hematological parameters and growth performance in broilers reared under standard and cold temperature conditions. Animal Feed Science and Technology, 185(1-2): 60-9. doi: https://doi.org/10.1016/j.anifeedsci.2013.07.002.

Wang J, Cao F, Zhu Z, Zhang X, Sheng Q, Qin W. 2018. Improvement of quality and digestibility of Moringa oleifera leaves feed via solid-state fermentation by Aspergillus niger. International Journal of Chemical Reactor Engineering, 16(12): 1-14. doi: https://doi.org/10.1515/ijcre-2018-0094.

Xie P, Huang L, Zhang C, Zhang Y. 2016. Nutrient assessment of olive leaf residues processed by solid-state fermentation as an innovative feedstuff additive. Journal of Applied Microbiology, 121(1): 28-40. https://doi.org/10.1111/jam.13131.

Yanez Ruiz D, Moumen A, Martin Garcia A, Molina Alcaide E. 2004. Ruminal fermentation and degradation patterns, protozoa population, and urinary purine derivatives excretion in goats and wethers fed diets based on two-stage olive cake: Effect of PEG supply. Journal of Animal Science, 82(7): 2023-32. doi: https://doi.org/10.2527/2004.8272023x.

Zhang X, Zhao L, Cao F, Ahmad H, Wang G, Wang T. 2013. Effects of feeding fermented Ginkgo biloba leaves on small intestinal morphology, absorption, and immunomodulation of early lipopolysaccharide-challenged chicks. Poultry Science, 92(1): 119-30. doi: https://doi.org/10.3382/ps.2012-02645.

Zhao L, Zhang X, Cao F, Sun D, Wang T, Wang G. 2013. Effect of dietary supplementation with fermented Ginkgo-leaves on performance, egg quality, lipid metabolism and egg-yolk fatty acids composition in laying hens. Livestock Science, 155(1): $77-85$.

doi: https://doi.org/10.1016/j.livsci.2013.03.024. 